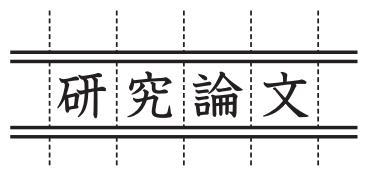

\title{
表面粗さを考慮した燃焼炎 3 段階合成法によるダイヤモンド皮膜合成

\author{
Synthesis of Diamond Films by Three-step Synthesis Method Using \\ Flame Combustion Considering Surface Roughness
}

\author{
高橋 護*・瀬川悟志**・神谷 修*** \\ Mamoru TAKAHASHI, Satoshi SEGAWA and Osamu KAMIYA
}

\author{
(Received November 11 2015)
}

\begin{abstract}
A flame combustion method enables the synthesis of diamond using acetylene-oxygen gas in ambient atmosphere. It has various advantages over other methods. We previously synthesized diamond films on a Mo substrate surface by the flame combustion method. In this method, most diamond films delaminate as a result of thermal stress during cooling. To prevent diamond film delamination for the synthesis of good diamond films, a three-step synthesis method was proposed. However, the surface roughness of synthesized diamond films by this method became large. In this study, to reduce the surface roughness of synthesized diamond films by flame combustion and to achieve good adhesion on the Mo substrate, the flow ratio of oxygen flow rate to acetylene flow rate and synthesis time of the three-step synthesis method were varied during the synthesis of diamond. We previously determined optimal ratio of oxygen flow rate $\left(F_{\mathrm{o}}=63.8 \mathrm{~cm}^{3} / \mathrm{s}\right)$ to acetylene flow rate $\left(F_{\mathrm{a}}=70.9 \mathrm{~cm}^{3} / \mathrm{s}\right)$ which was set to $R_{\mathrm{f}}=F_{\mathrm{o}} / F_{\mathrm{a}}=0.90$, because delamination free good crystalline growth could be obtained at $R_{\mathrm{f}}=0.90$. The acetylene flow rate was carefully varied in the range of $63.8-75.1 \mathrm{~cm}^{3} / \mathrm{s}\left(R_{\mathrm{f}}=0.85-1.00\right)$ of each synthesis time $(10 \mathrm{~min})$ of the three-step synthesis method. The oxygen flow rate was not varied, and it was $63.8 \mathrm{~cm}^{3} / \mathrm{s}$. To investigate the surface morphology and the surface roughness of synthesized diamond films, synthesized films were observed. The flow ratio and synthesis time of the three-step synthesis method affected the surface morphology and the surface roughness of synthesized diamond films. The surface roughness of the synthesized film was reduced by the proposed method in this study. The surface roughness in the Case 3 condition was the smallest in this experiment.
\end{abstract}

Key Words: Diamond Film, Flame Combustion, Surface Roughness, Three-step Synthesis Method, Gas Flow Rate, Synthesis Time

\section{1. 緒言}

近年、ダイヤモンドは高硬度、耐摩耗性、高い熱伝導率 等の優れた性質を有するため研摩や切削工具等の工業用材 料として幅広く利用されている。ここ最近では、引抜き用 ダイス ${ }^{1), 2} 、$ マイクロエンドミル ${ }^{3)}$ 、医療用デバイス ${ }^{4), 5}$ 、歯 科用回転切削工具 ${ }^{6), 7)}$ の表面へのダイヤモンド合成の研究 が行われている。また、航空分野やバイオメデイカル分野 で使用されている $\mathrm{Ti}$ 合金 ${ }^{8)}$ の表面へのダイヤモンド合成の 研究も行われ、その適用分野が広がってきている。このダ イヤモンドを金属材料表面に直接合成し、その接合強度が 高くなると耐摩耗性に優れた表面の高硬質処理が可能とな り、様々な分野においてその機能を活かしたさらなる利用 の拡大が期待される。
著者らは、化学気相堆積法（CVD 法）の一種であり大気 中でアセチレンー酸素ガスの燃焼炎によってダイヤモンド 皮膜を合成することが可能な燃焼炎法に着目し9),10)、金属 基板表面への成膜を行ってきた ${ }^{11)-18)}$ 。この燃焼炎法は、合 成速度がきわめて速い、装置が安定、安全、安価、また、 電力が不要である等の工業的に有利な特長を有している。 しかしながら、この方法でダイヤモンド皮膜の合成を行っ た際、合成終了後の冷却過程において熱応力が生じ、合成 皮膜が基板からはく離してしまう問題がある。そこで、こ のようなはく離を抑制する方法として、ダイヤモンドの合 成途中に皮膜の表面温度を 3 段階に変化させる 3 段階合成 法を提案し、合成皮膜のはく離の抑制を行ってきた ${ }^{13)}$ 。また、 過去の研究 ${ }^{13)-18)}$ において、はく離を抑制するためのダイヤ モンド皮膜合成の諸条件に注目し、各パラメータが合成皮

* 秋田大学大学院工学資源学研究科 共同ライフサイクルデザイン工学専攻（† 010-8502 秋田県秋田市手形学園町1-1） Cooperative Major in Life Cycle Design Engineering, Graduate School of Engineering and Resource Science, Akita University (1-1 Tegatagakuen, Akita, Akita, 010-8502 Japan)

**秋田大学大学院工学資源学研究科 共同ライフサイクルデザイン工学専攻（† 010-8502 秋田県秋田市手形学園町 1-1） Cooperative Major in Life Cycle Design Engineering, Graduate School of Engineering and Resource Science, Akita University (1-1 Tegatagakuen, Akita, Akita, 010-8502 Japan)

(現：旭ダイヤモンド工業株)（厂 102-0094 東京都千代田区紀尾井町 4-1）

Asahi Diamond Industrial Co., Ltd. (4-1 Kioi, Chiyoda, Tokyo, 102-0094 Japan))

*** * 秋田大学大学院工学資源学研究科 機械工学専攻 ( $\bar{T}$ 010-8502 秋田県秋田市手形学園町 1-1)

Department of Mechanical Engineering, Graduate School of Engineering and Resource Science, Akita University (1-1 Tegatagakuen, Akita, Akita, 010-8502 Japan) 
膜やはく離にどのような影響を及ぼすか調査を行い、接合 強度の高いダイヤモンド皮膜合成の最適条件の評価を行っ てきた。しかしながら、この際に合成されたダイヤモンド 皮膜の表面粗さに着目すると、合成皮膜の表面粗さが大き くなるという問題が発生した。ここで、合成ダイヤモンド 皮膜を施した切削工具で工作物の切削加工を行う際、切削 時に扔ける工作物の加工表面の粗さ精度や切削工具の性能 や切削寿命等の向上を考慮すると、合成皮膜の表面粗さをよ り小さくした粗さ精度に優れたダイヤモンド皮膜が求めら れる。また、医療界に打いても粗さ精度に優れたダイヤモン ド皮膜の有用性から、医療用デバイス上への表面粗さをより 小さくしたダイヤモンド皮膜の適用が求められている。

そこで、本研究では Mo 基板上に 3 段階合成法を適用し た燃焼炎法によりダイヤモンド皮膜の合成を行い、この際、 表面粗さを小さくすることが可能な合成方法を提案し、表 面粗さを考慮した皮膜の合成を行った。ここで、ダイヤモ ンド合成の際、含炭素燃料ガスの流量が多い時は核生成が 促進され、少ない時は逆に核生成が促進されず核成長が促 進されるという報告がある ${ }^{19}$ 。したがって、本研究におい て含炭素燃料ガスであるアセチレンの流量に着目して、3 段階合成中の各段階に扔いてアセチレンと酸素の流量比を 合成時間帯と共に段階的に変化させ、ダイヤモンド皮膜の 合成を行った。この際、各々の条件で得られた合成皮膜に 発生するはく離についての検討を行い、また、合成皮膜の 観察、さらには、合成皮膜の表面粗さの測定を行った。こ こで、各々の条件で合成された皮膜から得られた観測結果 の比較検討を行い、アセチレンと酸素の流量比ならびに合 成時間帯を段階的に変化させることで、合成皮膜のはく離 や合成皮膜ならびに合成皮膜の表面粗さにどのような影響 を及ほすか調査を行った。

\section{2. 実験方法}

\section{1 基板}

本実験において、基板は、高融点金属で炭化物を作成し やすく炭素の拡散係数が小さい純度 $99.9 \%$ のモリブデン (Mo) を用い、直径 $10 \mathrm{~mm}$ 、厚さ約 $3 \mathrm{~mm}$ の円盤状のものを 使用した。また、基板表面をエメリーペーパで一方向に研 摩するスクラッチング処理を施した。また、ダイヤモンド 合成の成長核として、アセトンに粒径約 $0.25 \mu \mathrm{m}$ のダイヤ モンド粒子を入れ、その中に Mo 基板を挿入し超音波洗浄 器で 30 分間種付け処理を施した。

\section{2 実験装置}

本実験に使用する実験装置を Fig.1 に示す。ここで、皮 膜の表面温度を一定に保つため、銅製のボックスに冷却水 を流し込んで冷却した。皮膜の表面温度は、非接触型の赤 外線放射型温度計により測定することが可能である。冷却 用装置は $100 \times 100 \times 55 \mathrm{~mm}^{3}$ の銅製ボックスを使用し、こ

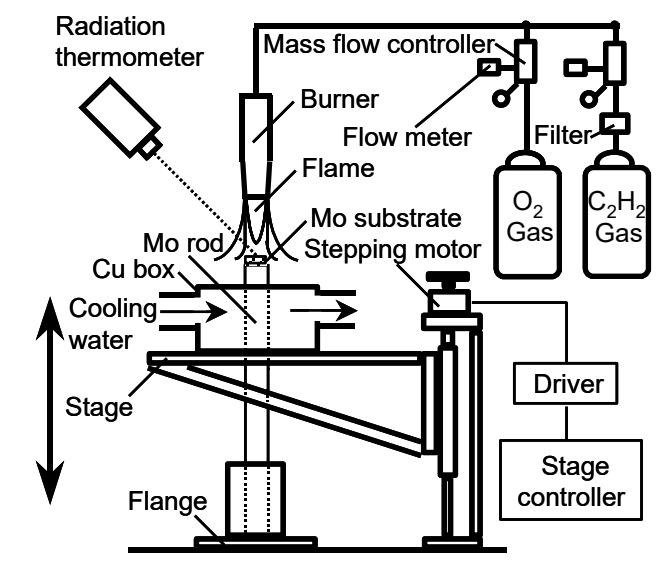

Fig.1 Experimental set up for synthesizing diamond by acetylene-oxygen combustion flame.

のボックスの中に冷却水を流し込み、反対方向から小型ポ ンプで吸い出した。ここで、直径 $10 \mathrm{~mm}$ の Mo 円柱棒を 彾却用の支柱としてボックスの中央に通し、テーブルにフ ランジで固定した。この支柱の上に基板を接着させ合成を 行った。この際、冷却を効率良く行うため基板と支柱の間 に熱伝導性の良い $\mathrm{Ag}$ ペーストを塗布し、473 K で炉内にお いて熱し接着を行った。

冷却用のボックスは上下移動可能なステージ上にあり、 冷却水面と皮膜表面の距離を変えることで皮膜表面温度を 変化させることができる。ステージにはステッピングモー 夕が取り付けられており、ドライバを介してステージコン トローラによって上下移動を制御することが可能である。

合成燃料にはアセチレンガスと酸素ガスを使用し、溶接 用のバーナにこれらの混合気体を導入して燃焼させた。こ こで、バーナの出口径は $1 \mathrm{~mm}$ ののを用いた。また、各々 のガス流量測定のためのガス流量計は、ガスの流量を正確 に制御が可能なマスフローコントローラを使用した。

\subsection{3 段階合成法}

著者らは、はく離の抑制を考慮した新たな合成方法とし て、ダイヤモンドの合成途中に皮膜の表面温度を 3 段階に 変化させる3 段階合成法を提案してきた ${ }^{13)}$ 。ここで、低温 (1300K 以下) での合成では、合成温度が適切なためダイ ヤモンド形態が八面体形状の良質なダイヤモンドが合成し やすいが接合強度は低く、高温（1400K 以上）の合成では、 ダイヤモンドの質が低下し硬度が下がってしまうカリフラ ワー形状、球形状のダイヤモンドが合成されるが接合強度

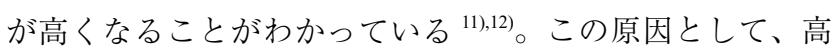
温になるにつれてダイヤモンド核の発生頻度が高くなり、 多くの微細核からなるカリフラワー状形態に変化し、さら に高温になると一部のダイヤモンドが炭化するため正常な 成長ができず球状になったものと考えられる。また、高 温（1400K 以上）で合成を行った皮膜には、ダイヤモンド 
の他に $\mathrm{Mo}_{2} \mathrm{C}$ が存在していることがわかっている ${ }^{13)}$ ここれ は、温度が上昇するにつれ、 $\mathrm{Mo}$ 基板の炭化物である $\mathrm{Mo}_{2} \mathrm{C}$ が生成されることより、 $\mathrm{Mo}_{2} \mathrm{C}$ とダイヤモンドが基板上に 堆積していると考えられる。ここで、合成終了後の冷却過 程において、基板とダイヤモンドの線膨張係数の違いによ り熱応力が発生し、はく離が発生する問題がある。この際、 接合強度の観点から考察すると、基板とダイヤモンドの間 に $\mathrm{Mo}_{2} \mathrm{C}$ が存在することで応力が緩和されることがわかっ ている ${ }^{13)}$ 。これは、基板となる Mo と線膨張係数が近い物 質を合成することにより、冷却過程中に生じる熱応力が緩 和され接合強度を高くすることができ、皮膜のはく離を抑 えることが可能となる。しかしながら、低温（1300K 以下） での合成では、この $\mathrm{Mo}_{2} \mathrm{C}$ が生成されないため、冷却過程 において発生した熱応力が緩和されず接合強度が低いま ま、皮膜のはく離が発生してしまう。この 3 段階合成法は、 低温（1300 K 以下）での合成と高温（1400 K 以上）での合 成を互いに補完し合う性質を巧みに用いた方法である。な お、この際、双方の性質が互いに悪影響を及ぼし合うこと が無いように十分考慮している。

ここで、3 段階合成法は、合成途中に皮膜表面温度を第 1 段階 $1423 \mathrm{~K}$ 、第 2 段階 $1223 \mathrm{~K}$ 、第 3 段階 $1323 \mathrm{~K}$ と変化さ せダイヤモンド合成を行う方法である ${ }^{13)}$ 。この際、第 1 段 階で合成される層でダイヤモンドと $\mathrm{Mo}_{2} \mathrm{C}$ 等を含んでいる 層を合成し、この第 1 段階である初期段階に、緩衝層とな る中間層を合成して接合強度を高め、はく離を抑制するこ とが可能である。また、第 2 段階では、皮膜の膜質を改善 するために良質のダイヤモンド結晶を生成しやすい $1223 \mathrm{~K}$ で合成を行う。第 3 段階では、膜厚を得るために $1223 \mathrm{~K} よ$ り合成速度の速い $1323 \mathrm{~K}$ として合成を行う。この際、合成 された皮膜の厚さは、3段階合成後で平均 $30 \mu \mathrm{m} / \mathrm{h}$ 程である。

本実験においても、この 3 段階合成法を用いてダイヤモ ンド皮膜の合成を行った。

\section{4 実験条件}

バーナの出口径 $1 \mathrm{~mm}$ の場合にダイヤモンドが合成可能 で、合成終了後の冷却過程において合成皮膜のはく離を抑 制することが可能である最適な合成条件 ${ }^{14)-17)}$ をTable 1 に 示す。本実験においても、この条件を用い合成を行った。 ここで、前処理のスクラッチング処理を施した際のエメ リーペーパの粒度を \#400 とした ${ }^{14), 15)}$ 。この際の前処理後の

Table 1 Conditions for diamond syntheses.

\begin{tabular}{l|c}
\hline \hline Reaction gas & $\mathrm{C}_{2} \mathrm{H}_{2}+\mathrm{O}_{2}$ \\
\hline Film surface temperature & $1223 \sim 1423[\mathrm{~K}]$ \\
\hline Pressure & $10^{5}[\mathrm{~Pa}]$ \\
\hline Emery paper grain size level & $\# 400$ \\
\hline Substrate surface roughness, $R_{\mathrm{a}}$ & $0.18[\mu \mathrm{m}]$ \\
\hline Inner cone-to-substrate distances & $1.5[\mathrm{~mm}]$ \\
\hline
\end{tabular}

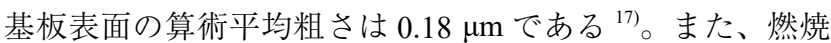
炎内における白心から基板表面までの距離を $1.5 \mathrm{~mm}$ とし た ${ }^{14), 15)}$ 。この際、本実験で用いる 3 段階合成法の合成時間は、 第 1、2、3 段階を各 20 分とし、全体の合計時間を 60 分と して合成を行った ${ }^{13)}$ 。

ここで、ダイヤモンド合成の際、含炭素燃料ガスの流量 が多い時は核生成が促進され、少ない時は逆に核生成が促 進されず核成長が促進されるという報告がある ${ }^{19)}$ 。したがっ て、本研究でも含炭素燃料ガスであるアセチレンの流量に 着目して、Table 2 ならびに Fig.2 に示すような Case 1〜 3

Table 2 Conditions for acetylene-oxygen gas flow rate.

\begin{tabular}{l|c|c|c}
\hline \hline & Case 1 & Case 2 & Case 3 \\
\hline $\mathrm{C}_{2} \mathrm{H}_{2}$ Flow rate, $F_{\mathrm{a}}\left[\mathrm{cm}^{3} / \mathrm{s}\right]$ & $75.1-70.9$ & $70.9-67.4$ & $70.9-63.8$ \\
\hline $\mathrm{O}_{2}$ Flow rate, $F_{\mathrm{o}}\left[\mathrm{cm}^{3} / \mathrm{s}\right]$ & 63.8 & 63.8 & 63.8 \\
\hline Flow ratio, $R_{\mathrm{f}}=F_{\mathrm{o}} / F_{\mathrm{a}}$ & $0.85-0.90$ & $0.90-0.95$ & $0.90-1.00$ \\
\hline
\end{tabular}
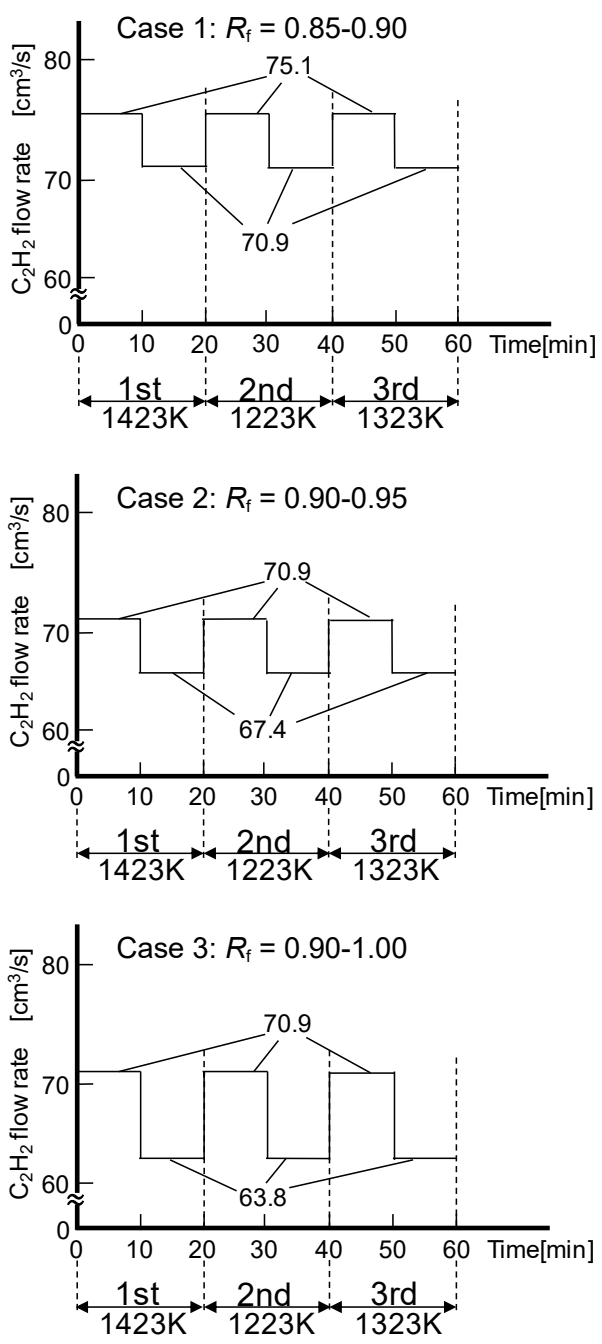

Fig.2 Outlines of conditions for acetylene-oxygen gas flow rate (Case 1-3). 
の各条件で、3 段階合成中の各段階においてアセチレンと 酸素の流量比を合成時間帯と共に段階的に変化させダイヤ モンド皮膜の合成を行った。この際、各々の条件で合成さ れた皮膜の観測を行い、得られた結果の比較検討を行い、 合成ダイヤモンド皮膜のはく離発生や合成皮膜ならびに表 面粗さにどのような影響を及ぼすか検討を行った。ここで 本研究では、酸素とアセチレンの流量比 $R_{\mathrm{f}}=\mathrm{O}_{2} / \mathrm{C}_{2} \mathrm{H}_{2}$ は、 過去の実験 ${ }^{16)}$ から得られた合成皮膜のはく離を最も抑制す ることが可能で、合成された結晶の結晶性が良くなる最適 な条件であるアセチレン流量 $70.9 \mathrm{~cm}^{3} / \mathrm{s}$ 、酸素流量 $63.8 \mathrm{~cm}^{3} /$ $\mathrm{s}$ から流量比 $R_{\mathrm{f}}=0.90$ を基準として条件を定めた。その值 を基準として、アセチレンと酸素の流量比を変化させた。 ここで、合成を行う際、3 段階合成の第 $1 、 2 、 3$ 段階にお いて 20 分間合成を行うが 13)、Case 1、2、3における各段階 (1 サイクル) での 20 分間の時間帯でアセチレン流量を 10 分ごとに変化させ合成を行った。この際、Case 1 は、アセ チレン流量を $75.1 \mathrm{~cm}^{3} / \mathrm{s}$ で 10 分間と $70.9 \mathrm{~cm}^{3} / \mathrm{s}$ で 10 分間の 1 サイクル（流量比 $R_{\mathrm{f}}=0.85-0.90 ） 、$ Case 2 は、アセチレン 流量 70.9 で 10 分間と $67.4 \mathrm{~cm}^{3} / \mathrm{s}$ で 10 分間の 1 サイクル（流 量比 $\left.R_{\mathrm{f}}=0.90-0.95\right) 、$ Case 3 は、アセチレン流量 $70.9 \mathrm{~cm}^{3} / \mathrm{s}$ で 10 分間と $63.8 \mathrm{~cm}^{3} / \mathrm{s}$ で 10 分間の 1 サイクル $\left(\right.$ 流量比 $R_{\mathrm{f}}=0.90$ -1.00）として段階的に変化させ、合計 3 サイクルで合成を 行った。

また、すべての Case において酸素流量は $63.8 \mathrm{~cm}^{3} / \mathrm{s}$ 一定 とし合成を行った。

\section{3. 実験結果と考察}

ここで、Table 2 ならびに Fig.2 に示すような Case 1～ 3 の条件でアセチレンと酸素の流量比を合成時間帯と共に段 階的に変化させダイヤモンド合成を行った。この際、得ら れた合成ダイヤモンド皮膜に発生するはく離について検討 を行い、また、合成皮膜の観察を行った。さらに、アセチ レン流量 $70.9 \mathrm{~cm}^{3} / \mathrm{s}$ 一定の $R_{\mathrm{f}}=0.90$ で合成を行ったダイヤ モンド皮膜と、Case 1〜3の条件で合成を行った皮膜の表 面粗さの測定を行った。この際、各々の条件で合成された 皮膜から得られた観測結果の比較検討を行い、これらの条 件の変化がダイヤモンド皮膜にどのような影響を及ぼすか 調査を行った。以下にその結果を示す。

\section{1 各条件で合成された皮膜のはく離}

まず、Case 1〜3の条件で燃料流量比を合成時間帯と共 に段階的に変化させ合成を行った皮膜のはく離の発生につ いて観察を行った。この際、ダイヤモンド合成終了後の冷 却過程において合成皮膜が界面からはく離が発生し、基板 上に皮膜がほとんど残っていない状態をはく離発生とし た。また、合成皮膜が界面からはく離が発生せず、基板上 に皮膜がほぼ残っている状態をはく離抑制とした。ここで、 観察を行った結果、Case 1〜3のすべての条件で合成され
た皮膜においてはく離発生は観察されず、はく離を抑制す ることができた。したがって、本実験より、アセチレンと 酸素の流量比を合成時間帯と共に段階的に変化させること で、Case 1〜3 の条件で合成を行った皮膜においてはく離 を抑制することができた。

\section{2 各条件で合成された皮膜の観察}

次に、走査型電子顕微鏡 (SEM：日本電子製 JSM5800）を用い、Case 1〜3の条件で合成を行った皮膜の表面 形態の観察を行った。その際に得られた SEM 画像を Fig.3 に示す。図より、Case 1の条件で合成された皮膜では、合 成された結晶の大きさは均一ではなく、球形状に近い形状 となった結晶が合成されていることがわかる。ここで、過 去の研究 ${ }^{16)}$ より、 $R_{\mathrm{f}}$ 值が小さくなると酸素が不足すること
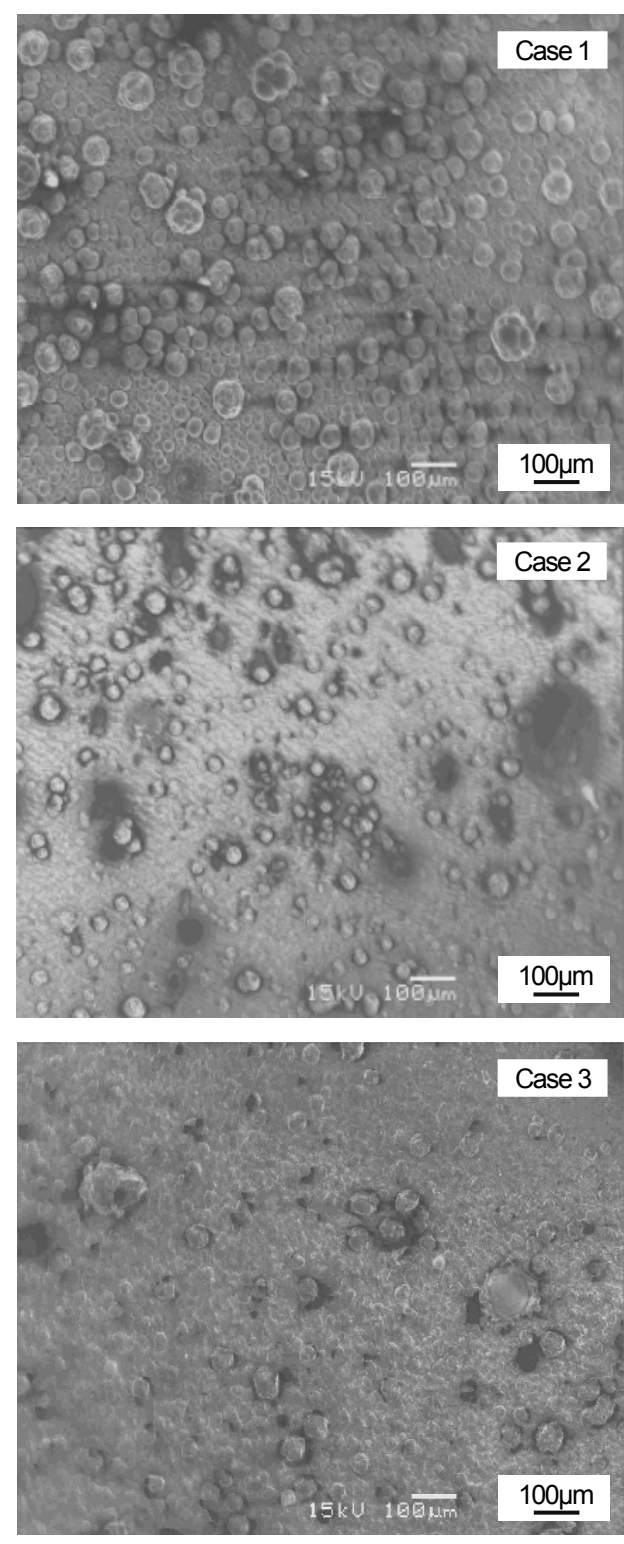

Fig.3 SEM images of synthesized diamond films in Case 1-3. 
によりエッジングが進まず結晶性が悪くなり、球形状の結 晶が合成されやすいことがわかっている。本研究において、 Case 1 では $R_{\mathrm{f}}=0.85-0.90$ で合成を行っており、 $R_{\mathrm{f}}=0.85$ における合成の際に酸素が不足しているため、エッジング が進まず結晶が球形状に近い形状となったと考えられる。 また、Case 2 の条件で合成された皮膜では、Case 1 の合成 皮膜の結晶よりも球形状に近い形状の結晶は少なくなり、 結晶の大きさも均一化しており、さらに、結晶同士がより 密な状態になっていることがわかる。しかしながら、結晶 の大きさがまだ均一化されていない部分も存在しているこ とがわかる。さらに、Case 3 の条件で合成された皮膜では、 球形状に近い形状の結晶がほとんど合成されておらず、ま た、結晶の大部分が均一化されていることがわかる。また、 結晶同士の隙間が少なく、結晶が密な状態の皮膜が合成さ れていることがわかる。

ここで、Case 1〜3の条件で合成された皮膜の特性を評 価するため、X 線回折装置（XRD：日本電子製 JDX-3530） を用い解析を行った。ここで得られた解析結果を Fig.4に 示す。図より、各 Case において合成された皮膜は、ダイヤ モンドの存在を示すダイヤモンド (111)、(220) 面のピーク を確認することができる。ここで、Case 2、3 の条件で合成 された皮膜になるにつれ、ダイヤモンド (220) 面がダイヤ モンド (111) 面のピークに比べて徐々に鋭くなっているこ とがわかる。特に Case 3 では、ダイヤモンド (220) 面がダ イヤモンド (111) 面のピークに比べて極めて鋭くなってい ることがわかる。このことより、Case 3 の条件で合成され た皮膜は、ダイヤモンド (220) 面が支配的なダイヤモンド 皮膜となっていることがわかる。以上のことより、アセチ レンと酸素の流量比を合成時間帯と共に段階的に変化させ ることで合成皮膜に影響を及ぼすことがわかった。

次に、走査型白色干涉計（SWLI：zygo 製 New View6K） を用い、流量比を $R_{\mathrm{f}}=0.90$ 一定の条件で合成を行ったダイ ヤモンド皮膜、ならびに Case $1 \sim 3$ の合成条件において合 成した皮膜の表面の算術平均粗さ $\left(R_{\mathrm{a}}\right)$ の測定を行った。こ こで得られた測定結果の平均值を Table 3 に示す。流量比 を $R_{\mathrm{f}}=0.90$ 一定の条件で合成を行ったダイヤモンド皮膜の 表面粗さは $R_{\mathrm{a}}=3.27 \mu \mathrm{m}$ 、Case 1 の条件では $R_{\mathrm{a}}=2.86 \mu \mathrm{m}$ 、 Case 2 の条件では $R_{\mathrm{a}}=2.43 \mu \mathrm{m}$ 、Case 3 の条件では $R_{\mathrm{a}}=1.63$ $\mu \mathrm{m}$ であった。以上のことより、流量比を一定で合成を行っ た皮膜の表面粗さよりも、アセチレンと酸素の流量比を合 成時間帯と共に段階的に変化させることで表面粗さを小さ くできることがわかった。さらに、本実験の Case 3 におい て合成皮膜の表面粗さが最も小さくなることがわかった。

3.3 燃料流量比を合成時間帯と共に段階的に変化させた際 の合成皮膜に及ぼす影響

本実験より、アセチレンと酸素の流量比を合成時間帯と 共に段階的に変化させることで、Case 1 3 の条件で合成
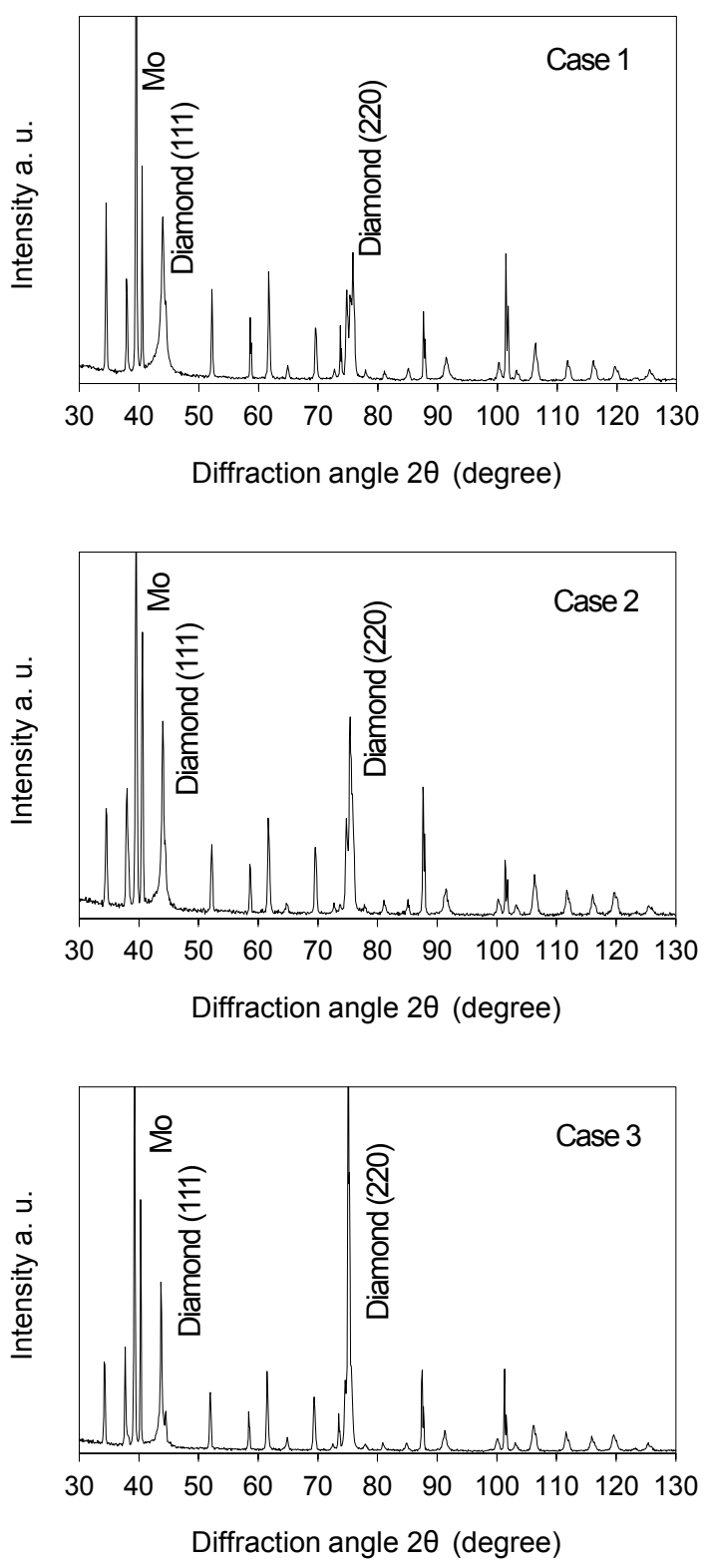

Fig.4 XRD patterns of synthesized diamond films in Case 1-3.

Table 3 Results of surface roughness of synthesized diamond films.

\begin{tabular}{c|c|c|c|c}
\hline \hline & $R_{\mathrm{f}}=0.90$ & Case 1 & Case 2 & Case 3 \\
\hline $\begin{array}{c}\text { Surface Roughness : } \\
R_{\mathrm{a}}[\mu \mathrm{m}]\end{array}$ & 3.27 & 2.86 & 2.43 & 1.63 \\
\hline
\end{tabular}

を行った皮膜において合成皮膜のはく離を抑制することが できた。ここで、Case 2、3では、初期段階にアセチレンと 酸素の流量比を $R_{\mathrm{f}}=0.90$ として合成を行っており、ダイヤ モンドの核生成率が十分であるため接触面積も十分に確保 され、はく離を抑制することができたと考えられる。また、 Case 1 においては、初期段階にアセチレンと酸素の流量比 
を $R_{\mathrm{f}}=0.85$ で合成を行っており、核生成率が流量比 $R_{\mathrm{f}}=$ 0.90 の時よりもさらに増加したため接触面積も増加し、は く離を抑制することができたと考えられる。ここで、ダイ ヤモンド合成の際、含炭素燃料ガスの流量が多い時は核生 成が促進され、少ない時は逆に核生成が促進されず核成長 が促進されるという報告がある ${ }^{19)}$ 。この際、燃料流量比を 合成時間帯と共に段階的に変化させ合成を行った際のアセ チレンの流量変化において、核生成と核成長の促進が段階 的にどのように繰り返し行われているか示した基本概念を Fig.5に示す。図のように、アセチレン流量が多い時に核 生成が促進、アセチレン流量が少ない時に核成長が促進さ れ、この核生成と核成長の促進が段階的に繰り返えされて いると考えられる。ここで、まず第 1 段階の初期のアセチ レン流量が多い時に核生成が促進され、その後、第 1 段階 のアセチレンの流量が少ない時に先に核生成された核の成 長が促進され、その後、第 2 段階でその核成長した結晶上 にさらに核生成、核成長が行われ、これらのことが繰り返 される。このことにより、最終的に隙間無く結晶が合成さ れると考えられる。また、第 1 段階に核生成ならびに核成 長した結晶上に第 2、3 段階で核生成ならびに核成長した結 晶が重なっていくことで、それら結晶が上方から押し付け るような状態になると考えられる。以上のことより、接合 強度が高くなり、はく離が抑制されると考えられる。

また、アセチレンと酸素の流量比を合成時間带と共に段 階的に変化させることで合成皮膜ならびに合成皮膜の表面 粗さに影響を及ぼすことがわかった。この際、流量比を $R_{\mathrm{f}}$ $=0.90$ 一定で合成を行った皮膜の表面粗さよりも表面粗さ を小さくできることがわかった。ここで、Case 1〜3の条 件で合成された皮膜では、流量比を合成時間帯と共に段階 的に変化させているため、Fig.5 の基本概念図のようにア セチレン流量が多い時間帯で核生成、アセチレン流量が少 ない時間帯で核成長が促進され、そのため成長した核同士 の隙間に新たな核が生成されその核が成長すると考えられ る。このサイクルを繰り返すことで、表面が流量比を一定 として合成を行った皮膜の結晶よりもより密な状態になる と考えられる。このことにより、Case 1〜3の条件で合成 された皮膜では、表面粗さが流量比を $R_{\mathrm{f}}=0.90$ 一定として 合成を行った皮膜よりも小さくなったと考えられる。さら に、本実験の Case 3 において合成皮膜の表面粗さが最も小 さくなることがわかった。Case 3 において、アセチレン流 量を段階的に変化させる過程におけるアセチレン流量が少 ない時間帯で、Case 1、2 の条件よりアセチレン流量が最も 少なくなっている。そのため、Case 1、2の条件よりも各段 階で生成された核において成長した結晶の結晶性に違いが 生じ、このことにより表面粗さに差異が発生したと考えら れる。Case 1 では球形状に近い形状の結晶が合成されてお り、Case 3 においては、球形状に近い形状の結晶がほとん ど合成されていないことがわかる。これは、アセチレンと
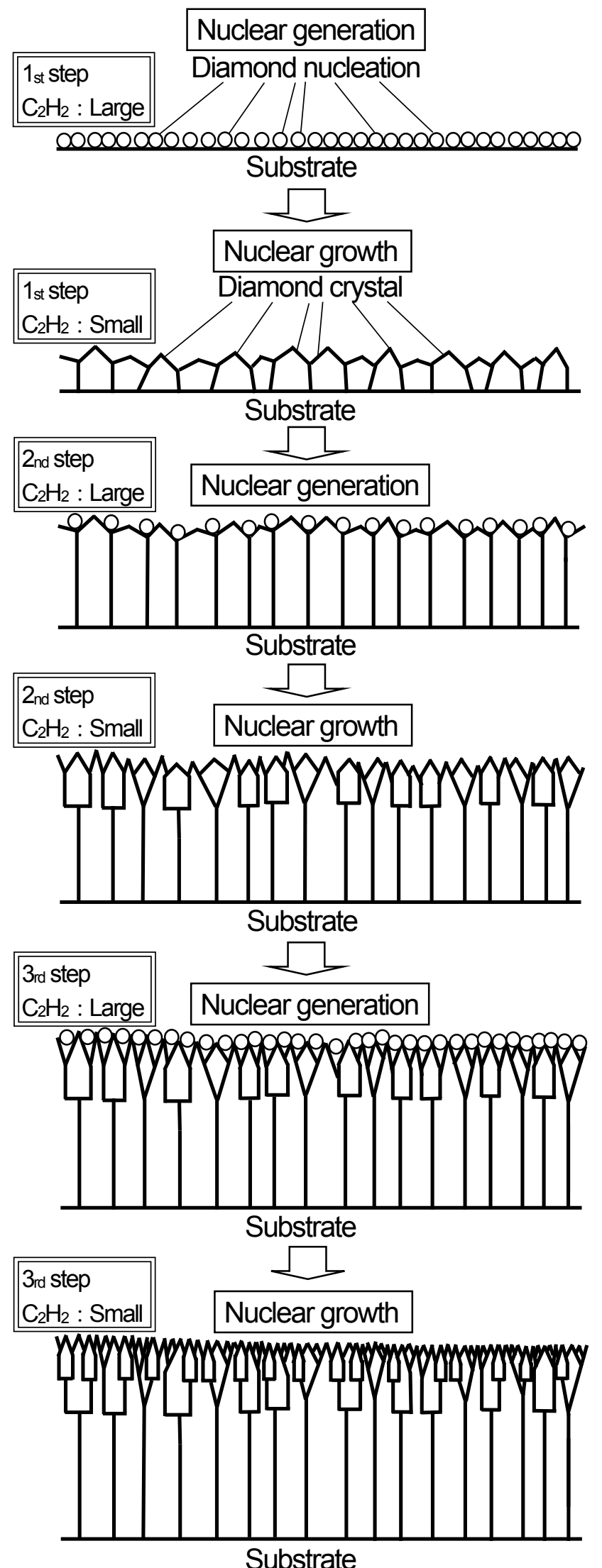

Fig.5 Cross-section morphologies of growth process of synthesized diamond films. 
酸素の流量比の違いにより生じていると考えられる。ここ で、Case 3 ではダイヤモンド (220) 面が、Case 1、2の条件 で合成を行った皮膜よりも支配的となっており、このこと により表面粗さの低減につながったと考えられる。

\section{4. 結言}

本研究では Mo 基板上に 3 段階合成法を適用した燃焼炎 法によりダイヤモンド皮膜の合成を行い、その際、表面粗 さを考慮したダイヤモンド皮膜の合成を行った。ここで、 表面粗さを小さくすることが可能な合成方法として、アセ チレンの流量に着目し、3 段階合成中の各段階においてア セチレンと酸素の流量比を合成時間帯と共に段階的に変化 させ、ダイヤモンド皮膜の合成を行った。この際、各々の 条件で合成した皮膜に発生するはく離の検討を行い、また、 合成皮膜の観察ならびに合成皮膜の表面粗さの測定を行っ た。ここで、各々の条件で合成された皮膜から得られた観 測結果の比較検討を行い、燃料流量比を合成時間帯と共に 段階的に変化させることで合成皮膜のはく離や合成皮膜な らびに合成皮膜の表面粗さにどのような影響を及ぼすか調 査を行った。その結果、以下のようなことが明らかになった。

本実験より、アセチレンと酸素の流量比を合成時間帯と 共に段階的に変化させることで、Case 1〜3の条件で合成 を行った皮膜においてはく離を抑制できることがわかっ た。

また、アセチレンと酸素の流量比を合成時間帯と共に段 階的に変化させることで合成皮膜に影響を及ぼすことがわ かった。

さらに、アセチレンと酸素の流量比を合成時間帯と共に 段階的に変化させることで表面粗さに影響を及ぼすことが わかった。この際、流量比を一定で合成を行った皮膜の表 面粗さよりも表面粗さを小さくできることがわかった。さ らに、本実験における Case 3 の条件で合成を行った皮膜に おいて、表面粗さを最も小さくすることができることがわ かった。

以上のことより、燃料流量比を合成時間帯と共に段階的 に変化させ合成を行った際のアセチレンの流量変化におい て、核生成と核成長の促進を段階的に繰り返し行わせるこ とではく離を抑制でき、また、合成皮膜ならびに表面粗さ に影響を与えることができ、かつ、表面粗さを小さくでき ることがわかった。

\section{謝 辞}

本研究の遂行に当たり、表面粗さの測定に関して走査型 白色干渉計（SWLI：zygo 社製 New View6K）を使用させて 頂いた秋田県産業技術センターに感謝の意を表します。

\section{引用文献}

1) S. Fanghong, M. Yuping, S. Bin, Z. Zhiming and C. Ming : Diamond and Related Materials, 18-2-3 (2009) 276-282.

2) B. Shen, F. Sun, Z. Zhang, H. Shen and S. Guo : Transactions of Nonferrous Metals Society of China, 23-1 (2013) 161-169.

3) J. P. Heaney, V. A. Sumant, D. C. Torres, W. R. Carpick and E. F. Pfefferkorn : Diamond and Related Materials, 17-3 (2008) 223-233.

4) R. J. Narayan, W. Wei, C. Jin, M. Andara, A. Agarwal, R. A. Gerhardt, C. C. Shih, C. M. Shih, S. J. Lin, Y. Y. Su, R. Ramamurti and R. N. Singh : Diamond and Related Materials, 15-11-12 (2006) 1935-1940.

5) L. Yang, B. W. Sheldon and T. J. Webater : Biomaterials, 30-20 (2009) 3458-3465.

6) R. Polini, A. Allegri, S. Guarino, F. Quadrini, H. Sein and W. Ahmed : Thin Solid Films, 469-470 (2004) 161-166.

7) E. Salgueiredo, F. A. Almeida, M. Amaral, A. J. S. Fernandes, F. M. Costa, R. F. Silva and F. J. Oliveira : Diamond and Related Materials, 18-2-3 (2009) 264-270.

8) C. Z. Zhang, Y. S. Li, Y. Tang, L. Zhang, Y. Sun, Q. Yang and A. Hirose : Thin Solid Films, 527 (2013) 59-64.

9) 廣瀬洋一、岡田直道、小池広宣 : 燃焼研究、80 (1989) 1-17.

10) 廣瀬洋一：日本エネルギー学会、73-11 (1994) 973-979.

11) 神谷修、熊谷一男、山辰夫：溶射、33-1 (1996) 1-7.

12) 神谷修、堀金弘明、石川計：高温学会誌、26-4 (2000) 154-161.

13) 高橋護、伊藤俊一、神谷修、大好直: 日本機械学会論文集 $\mathrm{A}$ 編、 71-703 (2005) 578-583.

14) 高橋護、神谷修、大好直：高温学会誌、31-3 (2005) 154-159.

15) 高橋護、神谷修、大好直 : 高温学会誌、32-5 (2006) 295-304.

16) 高橋護、神谷修、大好直：日本機械学会論文集 $A$ 編、73-725 (2007) 125-130.

17) 高橋護、原田雄司、神谷修、大好直 : 高温学会誌、34-3 (2008) 136-143.

18) M. Takahashi, Y. Harada, O. Kamiya and T. Ohyoshi : Journal of Solid Mechanics and Materials Engineering, 3-6 (2009) 853-864.

19) Q. Wei, Z. M. Yu, M. N. R. Ashfold, Z. Chen, L. Wang and L. Ma : Surface and Coatings Technology, 205-1 (2010) 158-167. 